University of Wollongong

Research Online

Faculty of Engineering - Papers (Archive)

Faculty of Engineering and Information

Sciences

$1-1-2007$

\title{
Transmission Electron Microscopy Characterization of the Bake-Hardening Behavior of Transformation-Induced Plasticity and Dual-Phase Steels
}

Ilana B. Timokhina

Monash University, Ilana.Timokhina@eng.monash.edu.au

Peter D. Hodgson

Deakin University

E V. Pereloma

University of Wollongong, elenap@uow.edu.au

Follow this and additional works at: https://ro.uow.edu.au/engpapers

Part of the Engineering Commons

https://ro.uow.edu.au/engpapers/3520

\section{Recommended Citation}

Timokhina, Ilana B.; Hodgson, Peter D.; and Pereloma, E V.: Transmission Electron Microscopy

Characterization of the Bake-Hardening Behavior of Transformation-Induced Plasticity and Dual-Phase

Steels 2007, 2442-2454.

https://ro.uow.edu.au/engpapers/3520

Research Online is the open access institutional repository for the University of Wollongong. For further information contact the UOW Library: research-pubs@uow.edu.au 


\title{
Transmission Electron Microscopy Characterization of the Bake-Hardening Behavior of Transformation-Induced Plasticity and Dual-Phase Steels
}

\begin{abstract}
I.B. TIMOKHINA, P.D. HODGSON, and E.V. PERELOMA
The effect of prestraining (PS) and bake hardening (BH) on the microstructures and mechanical properties has been studied in transformation-induced plasticity (TRIP) and dual-phase (DP) steels after intercritical annealing. The DP steel showed an increase in the yield strength and the appearance of the upper and lower yield points after a single BH treatment as compared with the as-received condition, whereas the mechanical properties of the TRIP steel remained unchanged. This difference appears to be because of the formation of plastic deformation zones with high dislocation density around the "as-quenched" martensite in the DP steel, which allowed carbon to pin these dislocations, which, in turn, increased the yield strength. It was found for both steels that the BH behavior depends on the dislocation rearrangement in ferrite with the formation of cell, microbands, and shear band structures after PS. The strain-induced transformation of retained austenite to martensite in the TRIP steel contributes to the formation of a complex dislocation structure.
\end{abstract}

DOI: $10.1007 / \mathrm{s} 11661-007-9258-7$

(C) The Minerals, Metals \& Materials Society and ASM International 2007

\section{INTRODUCTION}

ONE of the main aims of steel research for automotive body applications is to develop materials with the optimum combination of relevant properties, cost, and productivity. Transformation-induced plasticity (TRIP) and dual-phase (DP) steels have demonstrated a high ultimate tensile strength ( $\sim 800$ to $1000 \mathrm{MPa})$, while maintaining a high level of ductility (30 to $40 \mathrm{pct}$ ). ${ }^{[1,2]}$

The microstructure of DP steels consists of a soft, ductile, polygonal, ferrite matrix with hard martensite islands, and, in some cases, a small amount of retained austenite. ${ }^{[3]}$ The strength-ductility balance in this steel is controlled by the volume fraction of martensite. ${ }^{[3]}$ The TRIP steel microstructure contains polygonal ferrite, bainite, retained austenite, and a minor quantity of martensite. ${ }^{[4]}$ Both steels exhibit continuous yielding behavior, low yield point, and a high strain-hardening coefficient. $^{[5,6]}$ These characteristics have been attributed to an increase in the work-hardening parameters, through the continuous transformation of retained austenite to martensite in the TRIP steels and the formation of mobile dislocations and martensite twinning in the DP steels during forming. ${ }^{[7]}$ This results in a localized increase of the strain-hardening coefficient that

I.B. TIMOKHINA, Research Fellow, is with the Department of Materials Engineering, Monash University, Clayton, VIC 3800, Australia. Contact e-mail: Ilana.timokhina@eng.monash.edu.au P.D. HODGSON, Professor, ARC Federation Fellow, is with the Center for Material and Fiber Innovation, Deakin University, Geelong, VIC 3217, Australia. E.V. PERELOMA, Professor, Director of BlueScope Steel Metallurgy Centre, is with the School of Mechanical, Material and Mechatronics Engineering, University of Wollongong, Wollongong, NSW 2500, Australia.

Manuscript submitted September 17, 2006.

Article published online August 29, 2007. delays the onset of necking and ultimately leads to the high elongation without compromising the strength. ${ }^{[8]}$

In industrial processing, these steels undergo a finishing treatment, where the paint coating of the automotive body is baked at the temperatures of $150{ }^{\circ} \mathrm{C}$ to $200{ }^{\circ} \mathrm{C}$ for 20 to 30 minutes after forming. ${ }^{[9]}$ During this bakehardening $(\mathrm{BH})$ treatment, interstitial solute atoms, such as carbon, move to the dislocations produced during pressing and pin dislocations. ${ }^{[10]}$ The driving force for this solute redistribution is to reduce lattice energy. This reduction leads to solute diffusion toward dislocations and the formation of a Cottrell atmosphere. ${ }^{[11]}$

The use of the BH treatment has been proposed for both TRIP and DP steels, in addition to the work hardening, to increase the yield strength of these steels in the final body structure. ${ }^{[9]}$ This proposal should potentially lead to an increase in strength for the same thickness of steel sheet. The maximum increase $(100 \mathrm{MPa})$ has been observed in the TRIP and DP steels after 2 to 10 pct of prestraining (PS) in an interrupted tensile test to simulate the process of forming and paint baking of the car body. ${ }^{[9,12-14]}$ The yield strength increase was accompanied by the return of the yield point, a slight increase in the tensile strength, and a decrease in the elongation. ${ }^{[10]}$ Because there is no additional process step required, $\mathrm{BH}$ could result in good shape fixability and improved dent and crash resistance without compromising the production cost. ${ }^{[9]}$

In an earlier study of the BH mechanism, ${ }^{[15]}$ it was proposed that the increase in the yield strength in the DP steels after treatment was caused by the presence of mobile dislocations formed in ferrite around the dispersed martensite islands during their formation. However, publications ${ }^{[16,17]}$ have emphasized more complex mechanisms of $\mathrm{BH}$ in these steels as a result of the 
presence of the soft ferrite matrix and hard martensite phase in the microstructure and, in turn, the different behavior of phases during PS and the subsequent $\mathrm{BH}$ treatment. This research showed a number of stages during BH of DP steels, such as (1) Cottrell atmosphere and carbon-clustering formations in ferrite, (2) the precipitation stage in ferrite, and (3) tempering of martensite. ${ }^{[16-19]}$

The presence of retained austenite and bainite, in addition to ferrite and martensite, in the microstructure of TRIP steels makes the study of the BH mechanism more complex than in the case of DP steels. It has been proposed $^{[13]}$ that an increase in the yield strength of a TRIP steel after $\mathrm{BH}$ is a result of carbide-free bainite formation. The $\mathrm{BH}$ kinetics in bainite are much faster, because of the high carbon content and higher dislocation density that reduces the diffusion distance for dislocation pinning by carbon. ${ }^{[13]}$

However, as has been reported, ${ }^{[20]}$ the $\mathrm{BH}$ response depends on the formation of mobile dislocations in the strain-aged steels, but the importance of the dislocation rearrangements and their interaction during PS, and the further effect of the BH in the DP and TRIP steels, has not been clearly identified.

The aim of the current study is to understand the complex effect of microstructural changes that occur during the prestrain/BH treatment on the mechanical properties of intercritically annealed DP and TRIP steels.

\section{EXPERIMENTAL}

The TRIP and DP steels used in the current work were produced by a standard cold rolling and intercritical annealing (IA) at $780{ }^{\circ} \mathrm{C}$ for 180 seconds after the DP was quenched, when the TRIP steel was cooled to $400{ }^{\circ} \mathrm{C}$ and was held for 300 seconds, followed by quenching. The compositions of steels are shown in Table I. To study the effect of the $\mathrm{BH}$ and prestrain/BH treatment on the mechanical properties, the first set of samples was bake hardened at $175^{\circ} \mathrm{C}$ for 30 minutes without PS, and the second set was prestrained in tension to 5, 10, and 20 pet and then was baked at $175{ }^{\circ} \mathrm{C}$ for 30 minutes.

Room-temperature mechanical properties of the samples after processing and after additional $\mathrm{PS} / \mathrm{BH}$ treatment were determined using an Instron 4500 (Instron Pty Ltd., Monash University) servohydraulic tensile testing machine (Instron Pty Ltd., Melbourne, Australia) with a $100-\mathrm{kN}$ load cell. A series of six experiments was used to define the average values of ultimate and yield strengths, total, and uniform elongations. The yield strength was defined by the offset method of 0.2 pct. The strain-hardening coefficient $(n)$ was calculated from the stress-strain data using the following equation: ${ }^{[21]}$

Table I. Chemical Composition of Steels (Weight Percent)

\begin{tabular}{llllccl}
\hline Steel & \multicolumn{1}{c}{$\mathrm{C}$} & $\mathrm{Si}$ & $\mathrm{Mn}$ & $\mathrm{Al}$ & $\mathrm{Cu}$ & $\mathrm{Cr}$ \\
\hline TRIP & 0.12 & 1.77 & 1.39 & 0.031 & 0.005 & 0.02 \\
DP & 0.036 & 1.065 & 1.08 & 0.018 & 0.004 & 0.083 \\
\hline
\end{tabular}

$$
n=\frac{d(\ln \sigma)}{d(\ln \varepsilon)}
$$

where $\sigma$ is the true stress and $\varepsilon$ is the true strain.

The increase in the yield stress caused by the $\mathrm{BH}$ treatment was measured as the difference between the upper yield strength after treatment and the flow stress after PS. ${ }^{[18]}$

An X-ray diffraction analysis was performed using a PHILIPS* PW 1130 (40 kV, 25 mA) diffrac-

*PHILIPS is a trademark of Philips, Holland.

tometer equipped with a monochromator and $\mathrm{Cu} K_{\alpha}$ radiation to confirm the amount of martensite and retained austenite formed in the microstructure. Spectra were taken in the range of $2 \theta$ from 30 to $90 \mathrm{deg}$ with a 0.5 -deg step size. The integrated intensities of the $(200)_{\alpha},(211)_{\gamma},(200)_{\gamma}$, and $(220)_{\gamma}$ peaks were used in the direct comparison method. ${ }^{[2]}$ The X-ray diffraction data were also used to calculate the carbon concentration in the retained austenite lattice using the following equation: ${ }^{[23]}$

$$
\begin{aligned}
a_{\gamma}= & (0.363067+0.0783 /(1+0.2151(100 / \text { wt pct } \mathrm{C}-1))) \\
& \times(1+(24.92-1 /(1+0.2151(100 / \text { wtpct } \mathrm{C}-1))) \\
& \times 10^{-6}(\mathrm{~T}-727)
\end{aligned}
$$

The microstructure was characterized using transmission electron microscopy (TEM) on a PHILIPS CM 20, operated at $200 \mathrm{kV}^{* *}$. Thin foils for TEM

**PHILIPS is a trademark of Philips Electronic Instruments Corp., Mahwah, NJ.

were prepared by twin jet electropolishing using a solution of 5 pet perchloric acid in methanol at $-20{ }^{\circ} \mathrm{C}$ and an operating voltage of $30 \mathrm{~V}$. Microband and cell thicknesses were measured by the linear intercept method on 4 to 5 TEM negatives at a magnification of 11,500 times. The dislocation density was calculated by measuring the total dislocation line length in a unit volume of crystal, yielding a parameter in terms of length $(\mathrm{m}) / \mathrm{m}^{3}$. So, the dislocation density $(\mathrm{M})$ is given by ${ }^{[24]}$

$$
\Lambda=2 N_{L} / L t
$$

where $N_{L}$ is the number of intersections with dislocations, $L$ is the length of random lines, and $t$ is the foil thickness.

\section{RESULTS}

\section{A. Effect of Microstructure on the Mechanical Properties of Intercritical Annealed TRIP and DP Steels}

The microstructure of the TRIP steel consists of $\sim 70 \pm 3$ pct polygonal ferrite and $\sim 20 \pm 3$ pct retained 

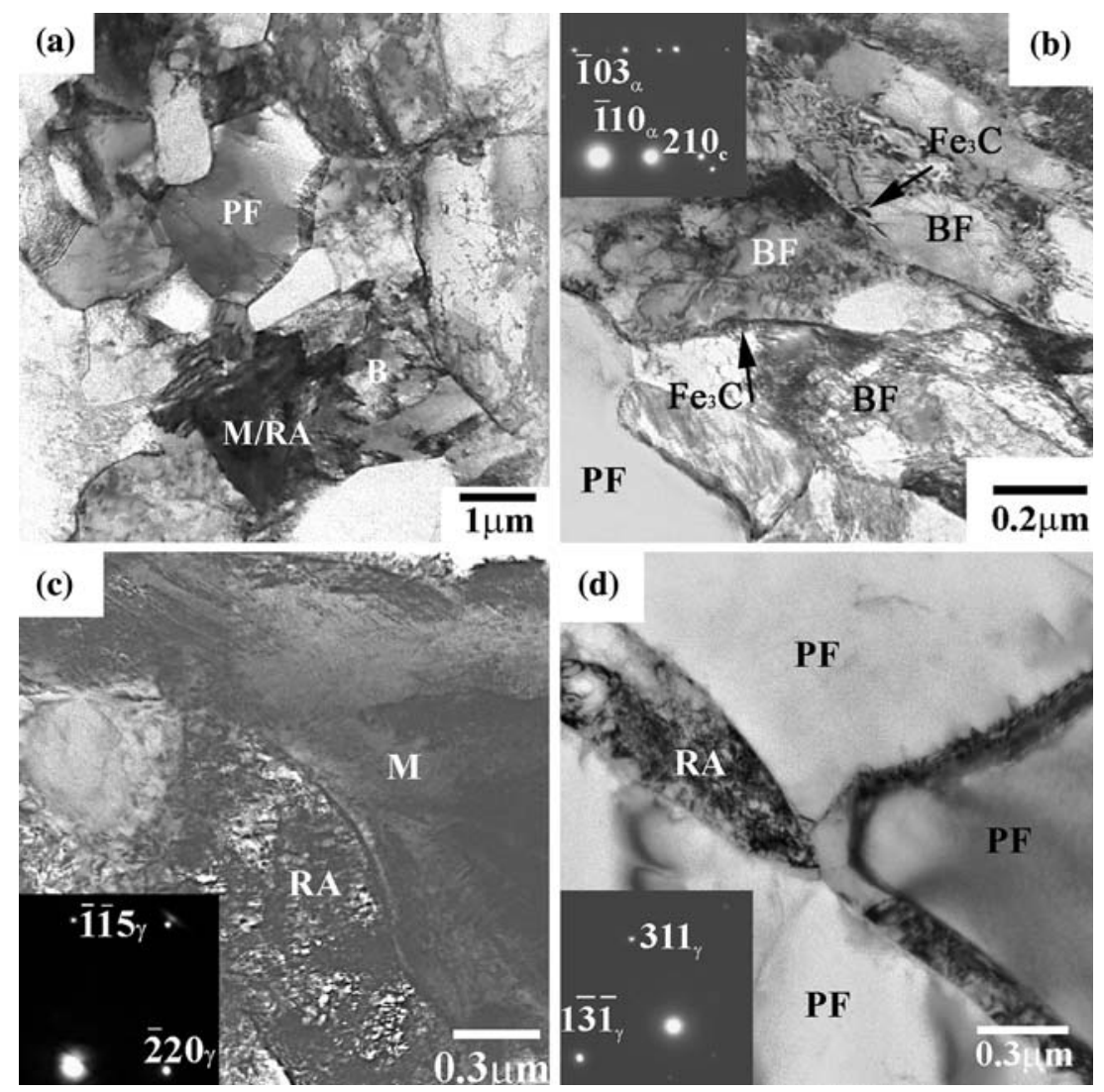

Fig. 1-TEM micrographs of TRIP after intercritical annealing: (a) general view, (b) upper bainite ([331 $\left.]_{\alpha} / /[001]_{c}\right)$, (c) dark-field image from $(\overline{2} 20)_{\gamma}$ of retained austenite/martensite constituent (zone axis of austenite is [552] $\gamma$ ), and $(d)$ retained austenite in ferrite (zone axis is [125] $]_{\gamma}$ ) PF: polygonal ferrite, M: martensite, RA: retained austenite, and BF: bainitic ferrite.

austenite with average carbon content of $1.2 \pm 0.05$ wt pct. The other main phases found in the microstructure were bainite and martensite (Figure 1(a)). The polygonal ferrite grain size was $4 \pm 1.5 \mu \mathrm{m}$. Bainite was present in two morphologies: (1) as bainitic ferrite laths or (2) as bainitic ferrite islands with retained austenite, martensite, or carbides in-between (Figure 1(b)). The retained austenite appeared to be in the form of a martensite/retained austenite constituent between the bainitic ferrite, or as islands between the polygonal ferrite grains (Figures 1(c) and (d)). The polygonal ferrite had a low dislocation density (Table II).
The microstructure of the DP steel consisted of $\sim 75 \pm 5$ pct polygonal ferrite and $\sim 15 \pm 4$ pct of martensite (Figure 2(a)). The ferrite grain size was $\sim 9 \pm 1.9 \mu \mathrm{m}$. The average dislocation density was lower than the TRIP steel (Table II). The TEM revealed the presence of a small amount of bainite (Figure 2(b)). Bainitic ferrite appeared to be in the form of layers with films of martensite, or retained austenite, between the layers (Figure 2(b)). Some retained austenite crystals were found between the polygonal ferrite grains (Figure 2(c)). Despite the fact that the average dislocation density of the DP steel is lower than the TRIP steel, the

Table II. Microstructural Characterization of Dislocation Structure in Polygonal Ferrite

\begin{tabular}{|c|c|c|c|}
\hline Condition & & TRIP & $\mathrm{DP}$ \\
\hline \multirow[t]{2}{*}{$\overline{I A}$} & dislocation density, $\times 10^{14} \mathrm{~m}^{-2}$ & $1.75 \pm 0.09$ & $0.96 \pm 0.04$ \\
\hline & average distance between dislocations, $\mathrm{nm}$ & $189 \pm 20$ & $309 \pm 28$ \\
\hline \multirow[t]{2}{*}{5 pct PS } & dislocation density, $\times 10^{14} \mathrm{~m}^{-2}$ & $3.45 \pm 0.05$ & $2.4 \pm 0.06$ \\
\hline & average distance between dislocations, $\mathrm{nm}$ & $66 \pm 14$ & $88 \pm 11$ \\
\hline \multirow[t]{2}{*}{5 pct $\mathrm{PS} / \mathrm{BH}$} & dislocation density, $\times 10^{14} \mathrm{~m}^{-2}$ & $2.7 \pm 0.05$ & $2.4 \pm 0.09$ \\
\hline & average distance between dislocations, $\mathrm{nm}$ & $54 \pm 7$ & $90 \pm 10$ \\
\hline \multirow[t]{2}{*}{10 pet PS } & dislocation density, $\times 10^{14} \mathrm{~m}^{-2}$ & $3.4 \pm 0.07$ & $3.04 \pm 0.04$ \\
\hline & average distance between dislocations, $\mathrm{nm}$ & $42 \pm 5$ & $72 \pm 12$ \\
\hline \multirow[t]{2}{*}{10 pct $\mathrm{PS} / \mathrm{BH}$} & dislocation density, $\times 10^{14} \mathrm{~m}^{-2}$ & $3.4 \pm 0.07$ & $3.6 \pm 0.05$ \\
\hline & average distance between dislocations, $\mathrm{nm}$ & $42 \pm 5$ & $68 \pm 4$ \\
\hline \multirow[t]{2}{*}{20 pet PS } & dislocation density, $\times 10^{14} \mathrm{~m}^{-2}$ & $3.8 \pm 0.09$ & $3.9 \pm 0.04$ \\
\hline & average distance between dislocations, $\mathrm{nm}$ & $42 \pm 4$ & $60 \pm 12$ \\
\hline
\end{tabular}



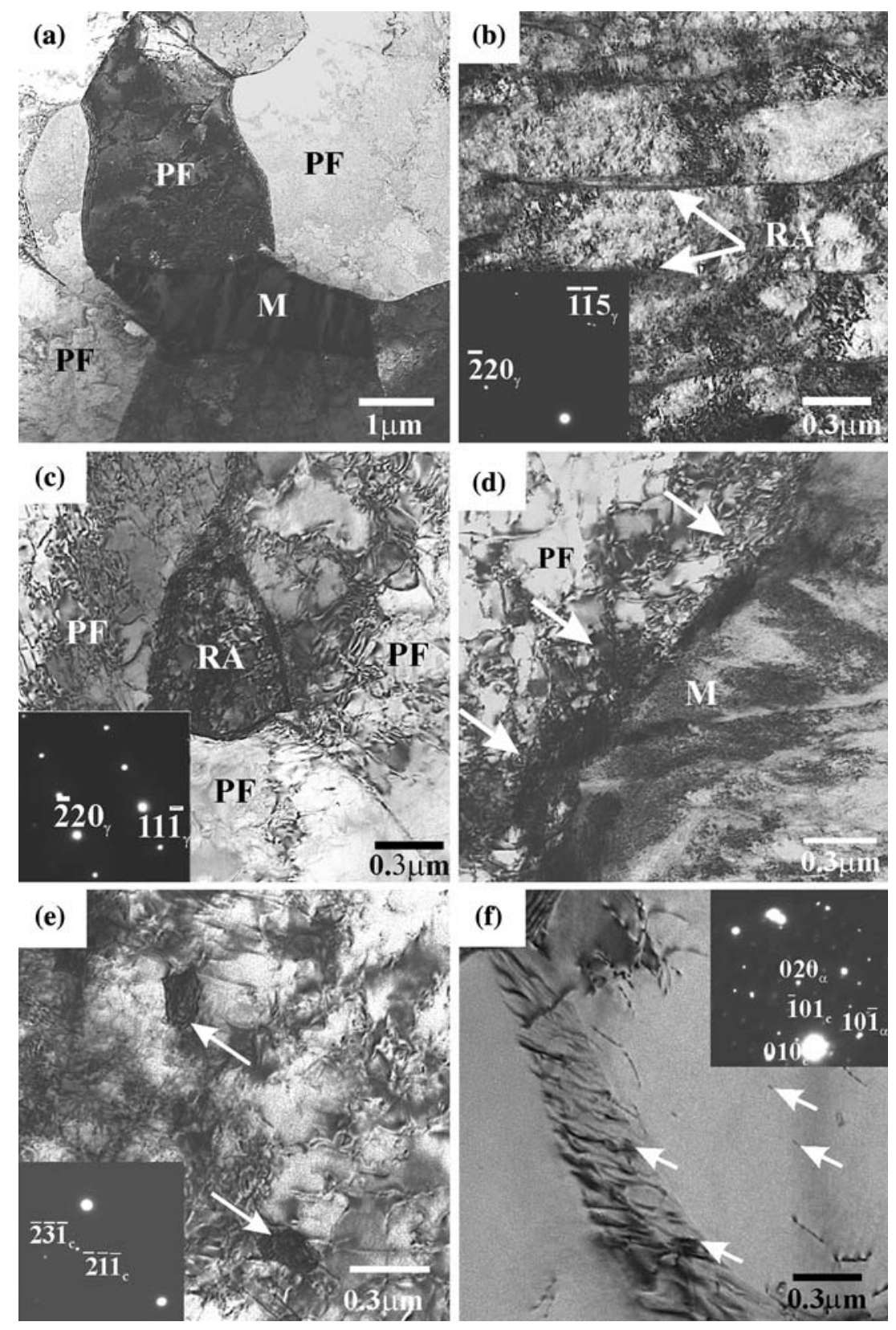

Fig. 2-TEM micrographs of intercritically annealed DP steels: $(a)$ general view, $(b)$ bainite (arrow indicates the retained austenite with zone axis of [552] $),(c)$ retained austenite in polygonal ferrite (zone axis is [112] $\left.]_{\gamma}\right),(d)$ martensite in polygonal ferrite (arrows indicate an increase in dislocation density), $(e)$ bright image of $\mathrm{Fe}_{3} \mathrm{C}$ carbides in bainite (arrows indicate carbides, zone axis is $[10 \overline{2}]_{c}$ ), and $(f)$ fine $\mathrm{Fe}_{3} \mathrm{C}$ carbides in the polygonal ferrite matrix $\left([101]_{\alpha} / /[101]_{c}\right)$, and dislocation pileup with carbides. PF: polygonal ferrite, M: martensite, and RA: retained austenite.

polygonal ferrite areas present in the vicinity of martensite displayed an increase in the dislocation density caused by the stress propagation of the martensite into the soft ferrite matrix associated with the volume increase when martensite forms (Figure 2(d)). The microstructure of the DP steel was characterized by a large number of fine and coarse $\mathrm{Fe}_{3} \mathrm{C}$ carbides within the bainite (Figure 2(e)) and ferrite grains (Figure 2(f)). The fine particles were observed along single dislocations and on the dislocation pile-up structure in the ferrite matrix (Figure 2(f)).

Both steels demonstrated a good combination of mechanical properties and continuous yielding behavior (Figures 3(a) and (b) and Table III). The strain-harden- ing exponent $(n)$ for the TRIP steel after IA showed a gradual increase to the maximum (0.27) at a strain of $\sim 0.16$ (Figure 4(a)), whereas the DP steel showed a steady behavior with an $n$ value of $\sim 0.13$ (Figure 4(b)). The strain-hardening rate curves for both steels showed a continuous exponential decrease (Figures 4(c) and (d)).

\section{B. Effect of BH and PS/BH Treatments on the Microstructure/Properties Relationship of DP and TRIP Steels}

The single BH treatment without PS caused the appearance of upper and lower yield points on the 


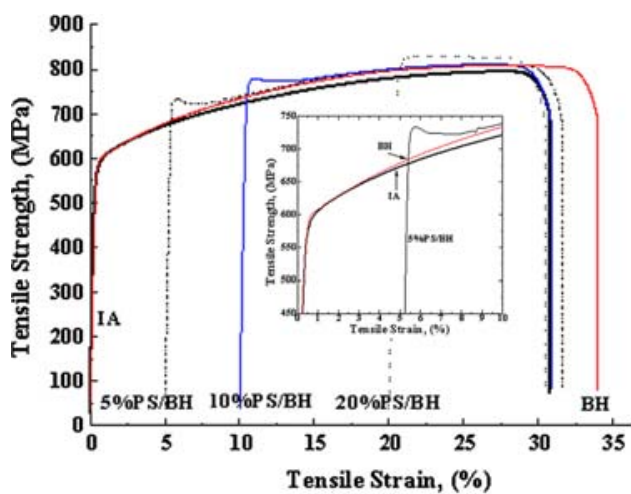

(a)

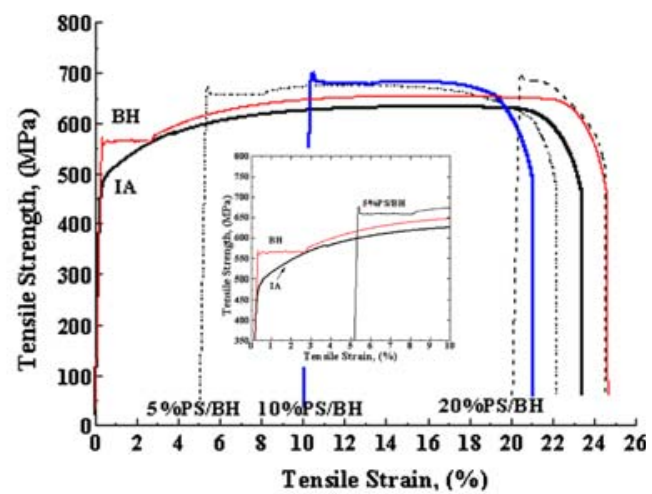

(b)

Fig. 3-Representative stress-strain curves of (a) TRIP and (b) DP steels.

Table III. Mechanical Properties of TRIP and DP Steels

\begin{tabular}{|c|c|c|c|c|c|c|}
\hline Steel & & UTS (MPa) & YS (MPa) & Uniform El (Pct) & Total El (Pct) & $\begin{array}{c}\text { Average } \mathrm{BH} \\
\text { Response }(\mathrm{MPa})\end{array}$ \\
\hline \multirow[t]{5}{*}{ TRIP } & IA & $795 \pm 10$ & $520 \pm 10$ & $27 \pm 3$ & $31 \pm 2$ & - \\
\hline & $\mathrm{BH}$ & $806 \pm 8$ & $520 \pm 10$ & $25 \pm 4$ & $34 \pm 2$ & - \\
\hline & 5 pct $\mathrm{PS} / \mathrm{BH}$ & $810 \pm 8$ & $735 \pm 5$ & $21 \pm 3$ & $27 \pm 2$ & $60 \pm 3$ \\
\hline & 10 pet $\mathrm{PS} / \mathrm{BH}$ & $811 \pm 8$ & $780 \pm 5$ & $17 \pm 3$ & $21 \pm 3$ & $57 \pm 3$ \\
\hline & 20 pct $\mathrm{PS} / \mathrm{BH}$ & $829 \pm 10$ & $840 \pm 8$ & $5 \pm 3$ & $11 \pm 2$ & $53 \pm 3$ \\
\hline \multirow[t]{5}{*}{ DP } & IA & $633 \pm 10$ & $425 \pm 10$ & $17 \pm 4$ & $23 \pm 3$ & - \\
\hline & $\mathrm{BH}$ & $655 \pm 5$ & $570 \pm 5$ & $17 \pm 5$ & $25 \pm 3$ & 145 (increase in YS) \\
\hline & 5 pct $\mathrm{PS} / \mathrm{BH}$ & $678 \pm 7$ & $676 \pm 7$ & $7 \pm 3$ & $17 \pm 3$ & $80 \pm 2$ \\
\hline & 10 pet $\mathrm{PS} / \mathrm{BH}$ & $683 \pm 5$ & $700 \pm 5$ & $4 \pm 2$ & $12 \pm 2$ & $73 \pm 2$ \\
\hline & 20 pct PS/BH & $702 \pm 5$ & $700 \pm 5$ & $<1$ & $5 \pm 2$ & $69 \pm 4$ \\
\hline
\end{tabular}

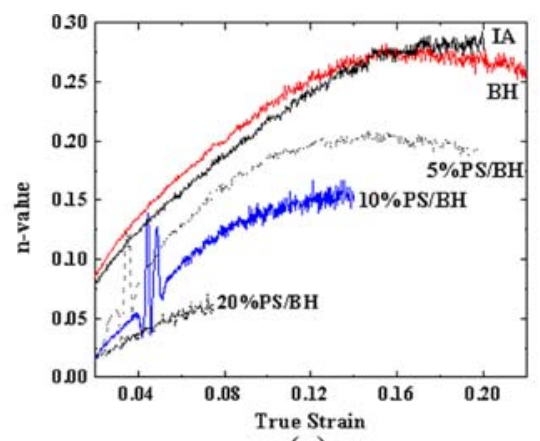

(a)

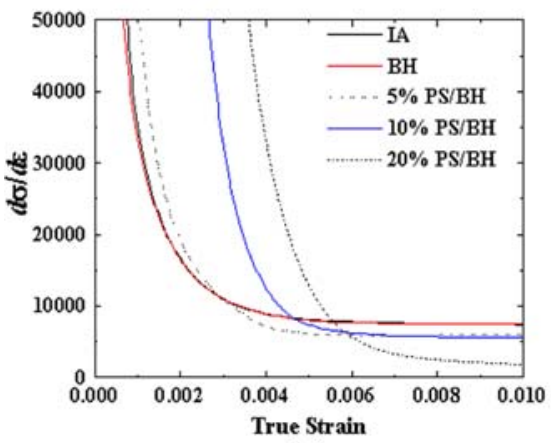

(c)

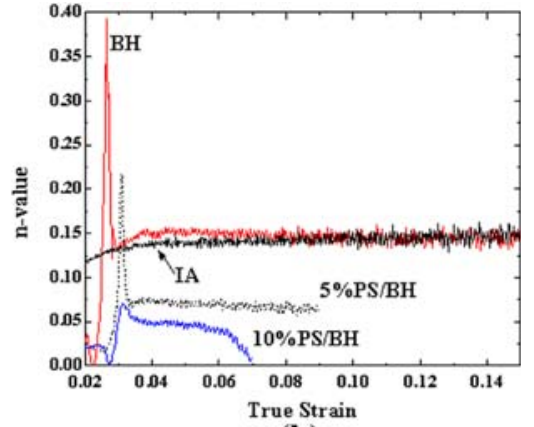

(b)

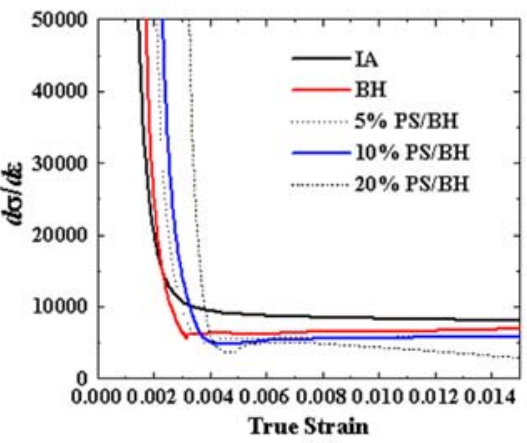

(d)

Fig. 4-Variation of the $(a)$ and $(b)$ strain-hardening exponent and $(c)$ and (d) rate with the true strain of (a) and (c) TRIP steel and (b) and (d) DP steel. 
stress-strain curve of the DP steel, whereas the stressstrain behavior of the TRIP steel was continuous (Figures 3(a) and (b)). Moreover, the yield strength in the DP steel after $\mathrm{BH}$ increased $\sim 150 \mathrm{MPa}$ as compared with the as-received condition, whereas the yield strength values for the TRIP steel were similar before and after heat treatment (Figures 3(a) and (b)). The total elongation values for both steels showed a slight increase (Figures 3(a) and (b)). The strain-hardening exponent of the DP steel displayed a sharp increase at a strain of 0.017 , whereas the $n$-curve of TRIP steel demonstrated behavior similar to the as-received condition. Moreover, the strain hardening rate curve for the TRIP steel showed a smooth, continuous decrease, whereas the DP steel had a sharper rate of change, with evidence of a discontinuity (e.g., local minima) (Figures 4(c) and (d)).

The X-ray study of the TRIP steel showed a slight decrease in the volume fraction of retained austenite. The TEM microanalysis on the bake-hardened DP and TRIP samples did not reveal significant microstructural changes as compared with the as-received condition, except for the growth of a number of $\mathrm{Fe}_{3} \mathrm{C}$ carbides in the polygonal ferrite and tempering of martensite, with the formation of carbides in the DP steel (Figures 5(a) and (b)).

Prestraining to 5 pct without an additional $\mathrm{BH}$ treatment led to a decrease in the volume fraction of retained austenite in the TRIP steel to $12 \pm 1$ pct with an average carbon content of $1.3 \pm 0.02 \mathrm{wt}$ pct. The use of TEM showed an increase in the dislocation density of the polygonal ferrite to $3.45 \pm 0.05 \times 10^{14} \mathrm{~m}^{-2}$ with an average distance between the dislocations of $66 \pm 14 \mathrm{~nm}$ (Figure 6(a) and Table II). The most affected grains were located in the vicinity of, or between, the bainite or newly formed martensite regions. The formation of dislocation cells, with an average size of $0.2 \mu \mathrm{m}$, was observed in the polygonal ferrite of the TRIP steel (Figure 6(b)). The interiors of the cells were free of dislocations, whereas the cell walls contained tangles of dislocations. Most of the martensite crystals contained twins (Figure 6(c)), as did some of the retained austenite crystals (Figure 6(d)).
The additional $\mathrm{BH}$ treatment led to the formation of $\mathrm{Fe}_{3} \mathrm{C}$ carbides between or within the martensite crystals and between the bainitic ferrite laths in the TRIP steel (Figures 7(a) through (d)). The fine $\mathrm{Fe}_{3} \mathrm{C}$ particles were also observed in the polygonal ferrite on the cell walls, and the particles appeared to be pinning dislocations (Figures 7(e) and (f)). The $\mathrm{BH}$ treatment also led to a decrease in dislocation density of the polygonal ferrite (Table II).

The stress-strain curve of the TRIP steel after 5 pct $\mathrm{PS} / \mathrm{BH}$ displayed an upper yield point with more rounded shape as compared with the DP steel (Figures 3(a) and (b)). The 5 pct PS/BH also led to an increase in the yield and ultimate tensile strengths with a decrease in total and uniform elongations (Table III). Moreover, the stress-strain curve showed a continuous increase in the flow stress with increasing strain after the drop at the lower yield point (Figure 3(a)). The BH response after PS was $\sim 60 \mathrm{MPa}$. The strain-hardening exponent exhibited two sharp maxima at strains of 0.027 and 0.036 (Figure 4(a)), whereas the strain-hardening rate still showed the continuous decrease (Figure 4(c)).

The DP steel also displayed a noticeable $\mathrm{BH}$ response ( $~ 80 \mathrm{MPa})$ with a decrease in total and uniform elongations (Table III). However, the stress-strain curve of the DP steel showed a behavior different from the TRIP steel, i.e., a sharper upper yield point and an unchangeable behavior of flow stress with increasing strain after reaching the maximum. The $n$ curve of the DP steel showed only a single sharp maximum with a lower $n$ value than after the single $\mathrm{BH}$ treatment (Figure 4(b)). The strain-hardening rate still showed the local minima (Figure 4(d)).

The DP steel, after 5 pct PS, displayed an increase in the average dislocation density of the polygonal ferrite (Table II). However, cell formation was not found in this steel. A large number of martensite crystals showed twinning (Figures 8(a) and (b)).

The PS of the TRIP steel to 10 pct led to a further decrease in the retained austenite volume fraction to $10 \pm 2$ pct, with an average carbon content of $1.3 \pm 0.03 \mathrm{wt}$ pct. It appeared that 10 pet PS initially affected the polygonal ferrite grains located in the

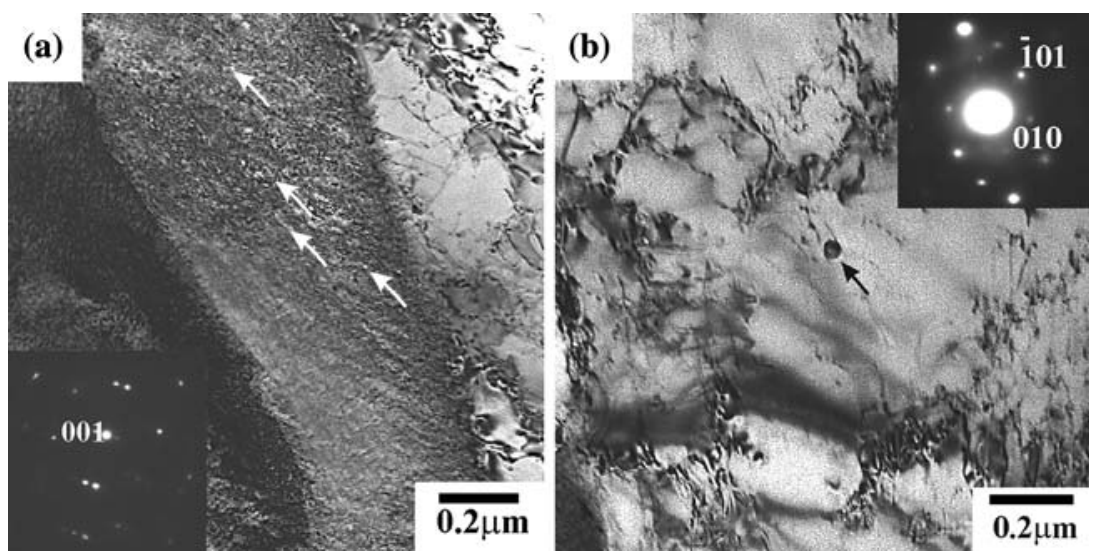

Fig. 5-Carbides in the bake-hardened DP steel: $(a)$ in martensite (zone axis is [100] $]_{c}$ ) and $(b)$ in ferrite (zone axis is [101] $]_{c}$. Arrows indicate carbides. 

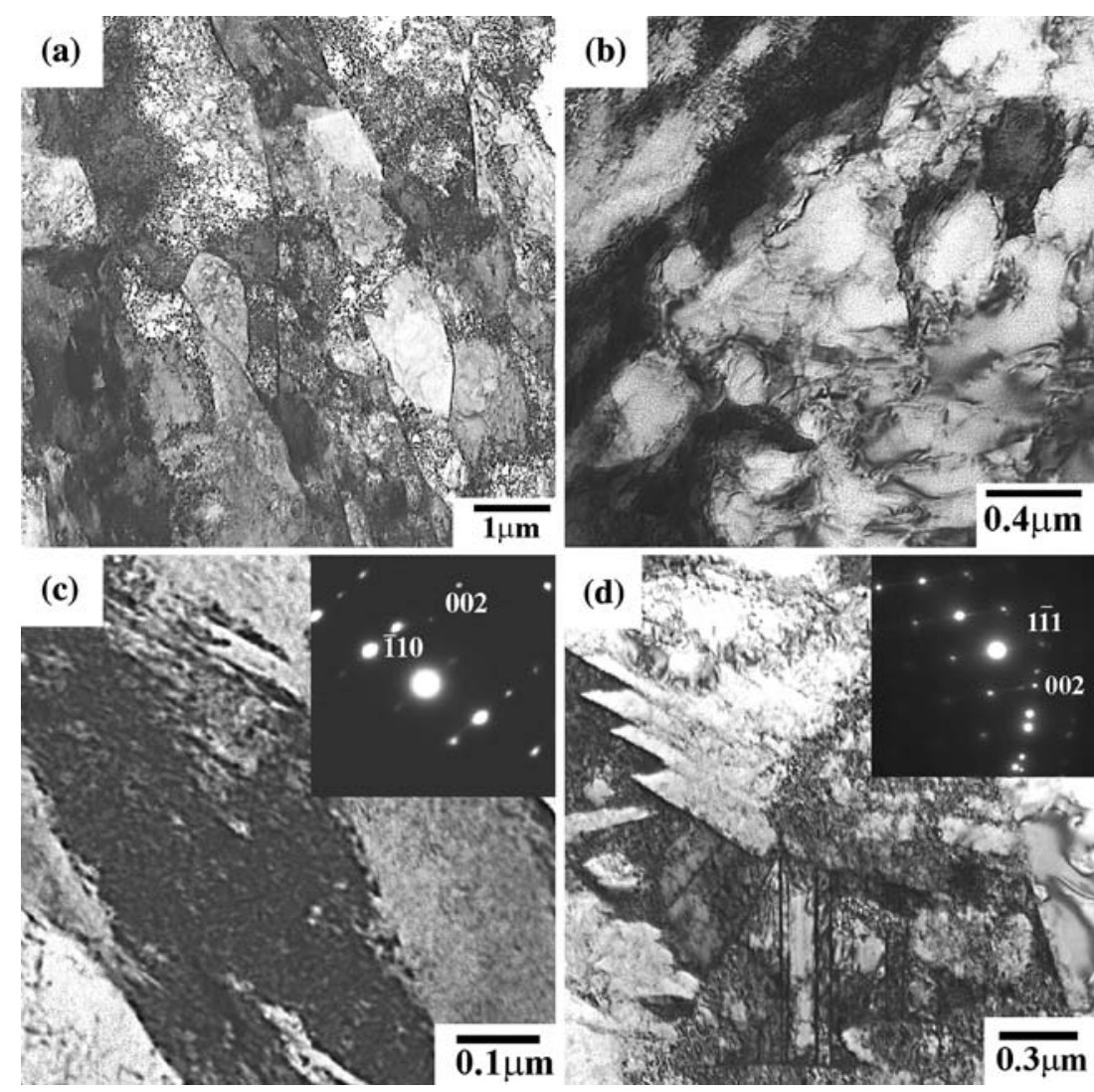

Fig. 6 - Bright-field image micrographs of TRIP steels after 5 pct of PS: $(a)$ general view, $(b)$ formation of cell structure, $(c)$ twin martensite (zone axis is $[110]_{\alpha}$, twin plane is $(121)_{\alpha}$ ), and $(d)$ twin austenite (zone axis is $[110]_{\gamma}$, twin plane is $(\overline{1} 11)_{\gamma}$ ).

vicinity of the second phase (Figure 9(a)). The use of TEM showed the formation of a complex dislocation structure in the polygonal ferrite with the presence of a cell-structure and microbands with an average thickness of $0.45 \pm 0.17 \mu \mathrm{m}$ (Figure 9(b)). These were parallel to the deformation direction, with walls consisting of dislocation assemblies similar to those in the cell walls. Some microbands displayed the formation of a cellstructure inside, perpendicular to the microband walls (Figure 9(b)). Despite microband and a cell-structure formation in ferrite, i.e., where some dislocations moved to the walls, the average dislocation density in the TRIP steel increased (Table II). The additional BH treatment in the TRIP steel led to the appearance of $\mathrm{Fe}_{3} \mathrm{C}$ peaks in the X-ray curve, which verified the increase in the number of carbides. These carbides were found in ferrite, within the martensite crystals, and between the bainitic ferrite. The 10 pct $\mathrm{PS} / \mathrm{BH}$ led to a further decrease in elongation with a $\mathrm{BH}$ response of $\sim 57 \mathrm{MPa}$ (Table III and Figure 3(a)). The stress-strain curve showed only a slight increase in the ultimate tensile strength, as compared with the as-received condition, and also a continuous increase in the flow stress with strain after the lower yield point (Figure 3(a)). The strain-hardening exponent also had two maxima at strains of 0.043 and 0.05 (Figure 4(a)), whereas the strain-hardening rate curve shifted to higher true strain values and showed a continuous exponential decrease (Figure 4(c)).
Prestraining of the DP steel to 10 pct was characterized by an increase in the average dislocation density in the polygonal ferrite (Table II). An increase in PS also led to the formation of a relaxed configuration of the dislocation structure, i.e., cell structure, developing because of dislocation movement (Figures 10(a) and (b)). Fine carbides were observed in the ferrite matrix; moreover, some were found on the dislocations (Figures 10(a) and (b)). X-ray analysis confirmed an increase in the number of iron carbides after the additional BH treatment in the 10 pct PS DP steel. Islands of decomposed, retained austenite, consisting of ferrite and carbides, were also found in the microstructure (Figure 10(c)). The mechanical properties after the $\mathrm{BH}$ treatment displayed a sharp decrease in the total elongation (12 pct), a slight increase in the UTS, and a decrease in the $\mathrm{BH}$ response $\sim 73 \mathrm{MPa}$ (Table III and Figure $3(\mathrm{~b})$ ). The $n$-hardening coefficient decreased to $\sim 0.07$ and displayed one peak with a rounded shape (Figure 4(b)). The strain-hardening rate also showed the rounded shape of local minima (Figure 4(d)).

The mechanical properties of the 20 pct PS/BH TRIP steel showed a drastic decrease in the uniform and total elongations and a slight decrease in the $\mathrm{BH}$ response (Table III and Figure 3(a)). This led to a decrease in the $n$ value and a change in its shape (Figure 4(a)). These mechanical properties were caused by the microstructural features formed in the microstructure after $20 \mathrm{pct}$ $\mathrm{PS}$, such as complex dislocation structures including cell 

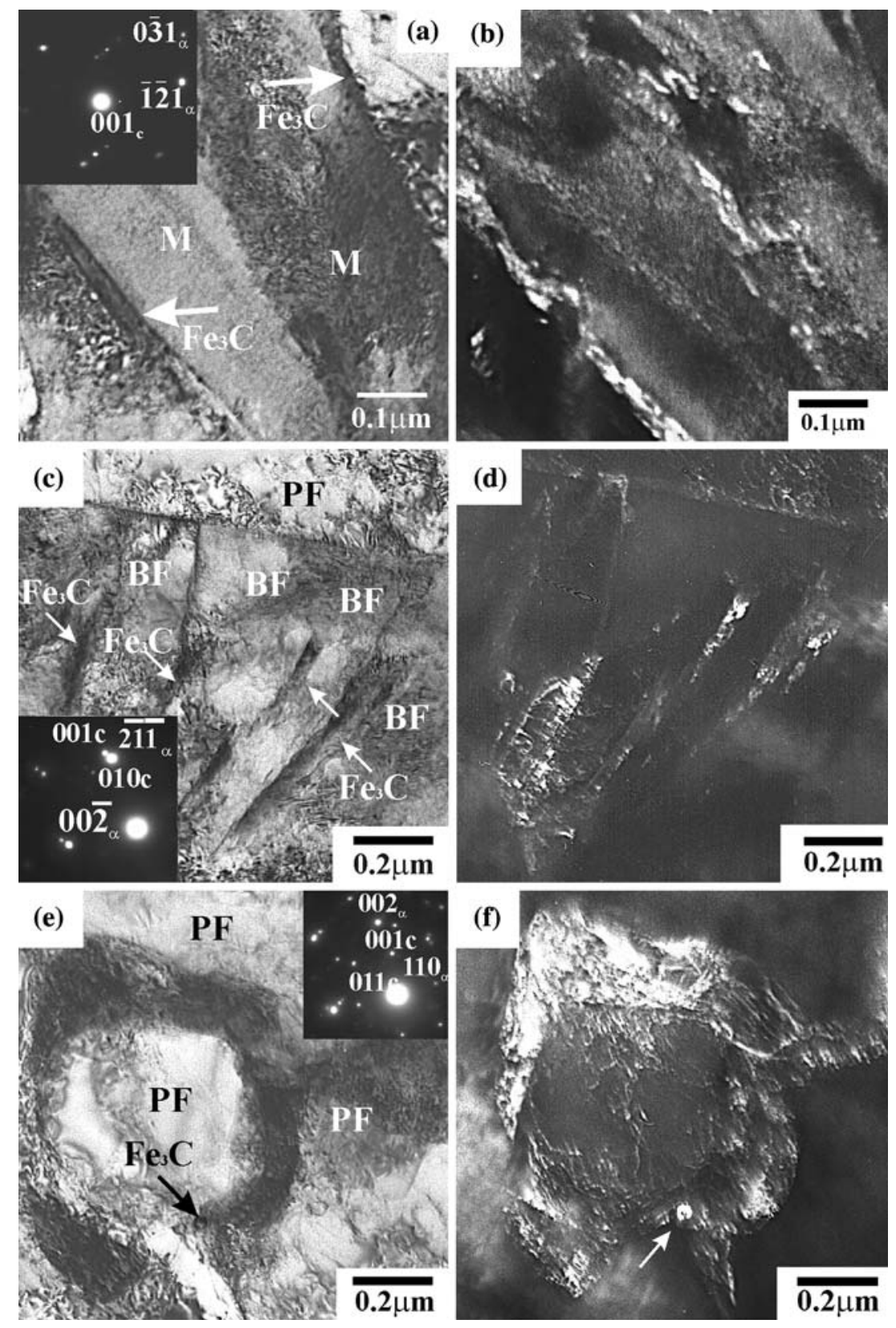

Fig. 7-TEM micrographs of TRIP steel after 5 pet PS/BH: $(a)$ bright and $(b)$ dark images of carbide formation within and between the martensite crystals $\left([113]_{\alpha} / /[\overline{2} 10]_{c}\right),(c)$ bright and $(d)$ dark images of carbide formation between the bainitic ferrite laths $\left([112]_{\alpha} / /[100]_{c}\right)$, and $(e)$ bright and $(f)$ dark images of fine carbides in polygonal ferrite $\left([110]_{\alpha} / /[100]_{c}\right)$. Arrows indicate carbides. PF: polygonal ferrite, BF: bainitic ferrite, and M: martensite.

structure, microbands, shear bands (Figure 11(a)), and a high density of dislocation tangles in the polygonal ferrite, transformation of nearly all retained austenite crystals to martensite, and the twinning of the remaining retained austenite crystals (Figure 11(b)). The shear bands were formed at angles of $\sim \pm 35$ deg with respect to the matrix microbands. Because of the complex nature of the dislocation structure, it was not possible to quantify the average dislocation density in the ferrite. A small amount of retained austenite $(\sim 5$ pct $)$ with a carbon content of $1.3 \mathrm{wt}$ pct was still present in the microstructure. The additional $\mathrm{BH}$ treatment appeared to lead to the decomposition of some retained austenite crystals with the formation of ferrite and carbides (Figure 11(c)).

Further increase in PS to 20 pct, followed by BH in the DP steel, led to a remarkable deterioration in elongation and a slight decrease in the $\mathrm{BH}$ response (Table III and Figure 3(b)). The strain-hardening rate curve displayed deeper local minima than after $10 \mathrm{pct}$ PS/BH (Figure 4(d)). This was associated with the formation of a dense deformation structure in the polygonal ferrite, such as equiaxed cells and microbands (Figures 12(a) through (c)). Martensite crystals displayed tempering, and some of them displayed twinning. 


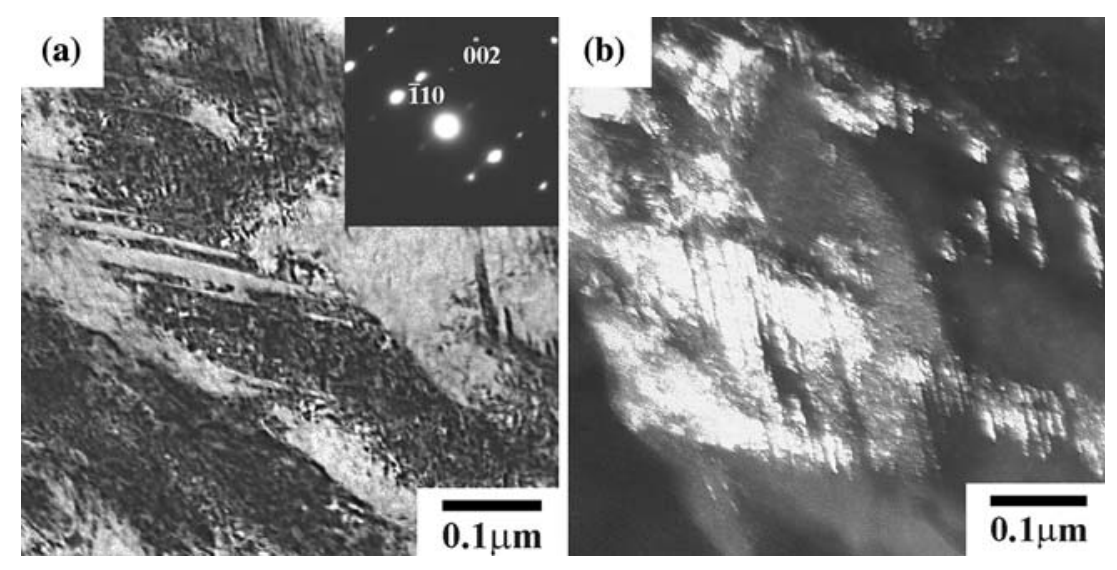

Fig. 8 - (a) Bright and $(b)$ dark (dark image from $(110)_{\alpha}$ ) images of martensite twining in the DP steel after 5 pct PS/BH (zone axis is [110] $]_{\alpha}$ twin plane is $\left.(121)_{\alpha}\right)$.
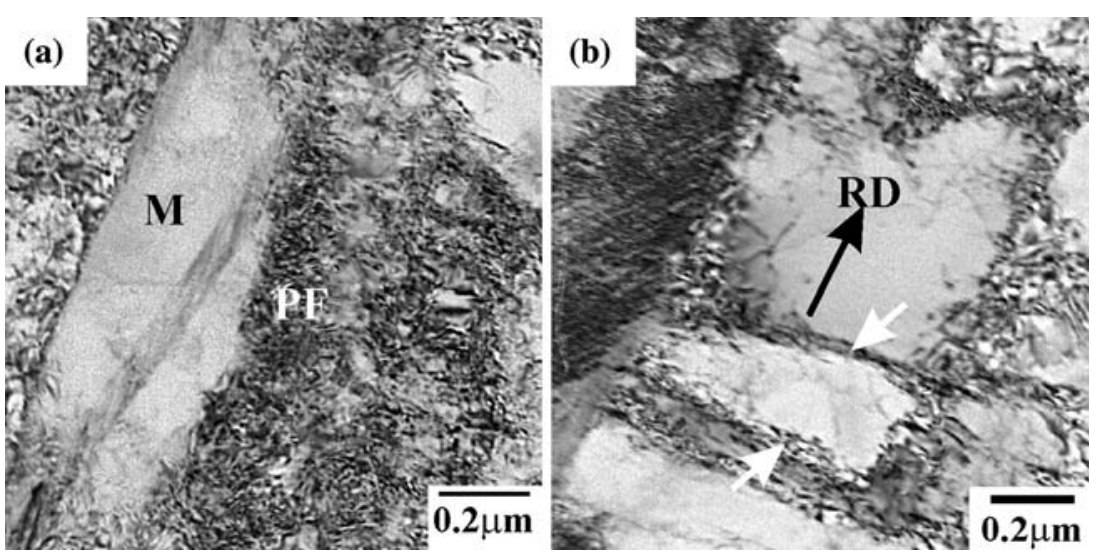

Fig. 9-Bright-field micrographs of $(a)$ increased dislocation density in ferrite and $(b)$ formation of microbands in ferrite in the 10 pct PS TRIP steel. Arrows indicate the formation of cells. PF: polygonal ferrite, M: martensite, and RD: rolling direction.

The X-ray spectrum displayed a slight increase in the volume fraction of carbides.

\section{DISCUSSION}

\section{A. Effect of the Single BH Treatment on the Structure- Property Relationship in the DP and TRIP Steels}

The multiphase microstructure formed in the TRIP and DP steels controls the combination of strength and ductility. The two steels showed several microstructural differences, such as (1) the DP steel contained $15 \mathrm{pct}$ martensite in a soft polygonal ferrite matrix, whereas TRIP had 20 pct retained austenite; (2) the DP steel showed a lower average dislocation density in the asreceived condition than did the TRIP steel; (3) the DP steel displayed a higher ability to form fine carbides than did the TRIP steel; (4) there was a higher dislocation density in the polygonal ferrite areas surrounding the martensite islands than in other ferrite areas of the DP steel; and (5) the ferrite grain size in the DP steel was twice that of the TRIP steel.

The increase in the yield strength $(\sim 145 \mathrm{MPa})$, after a single $\mathrm{BH}$ treatment and the appearance of the upper yield point, was only observed in the DP steel (Table III and Figure 3(b)). Moreover, the strain-hardening rate curves after $\mathrm{BH}$ of two steels demonstrated the different behaviors (Figures 4(c) and (d)). The presence of the upper yield point in the bake-hardened DP steel is evidence of dislocation pinning in the ferrite during $\mathrm{BH}$. In the DP ferrite-martensite microstructure, the strain is first concentrated in the ferrite, whereas the martensite remains undeformed at the early stages of deformation. ${ }^{[16,17]}$ Therefore, the strain-hardening rate behavior of the DP steel appears to be sensitive to the pinning of the mobile dislocations in the ferrite matrix. Hence, the transition from the continuous behavior of the strain-hardening rate curve of DP steel after processing, to the discontinuous behavior after $\mathrm{BH}$, is the formation of Cottrell atmospheres that pin the mobile dislocation in the ferrite. ${ }^{[11,16]}$ However, the average dislocation density of ferrite in the DP steel is lower than in the TRIP steel (Table II), so a more pronounced $\mathrm{BH}$ effect would be expected in the TRIP steel if the same carbon content exists in the ferrite. On the other hand, the formation of a high volume fraction of "as-quenched" martensite in a soft polygonal ferrite matrix during quenching led to the formation of the plastic deformation zones with a much higher dislocation 

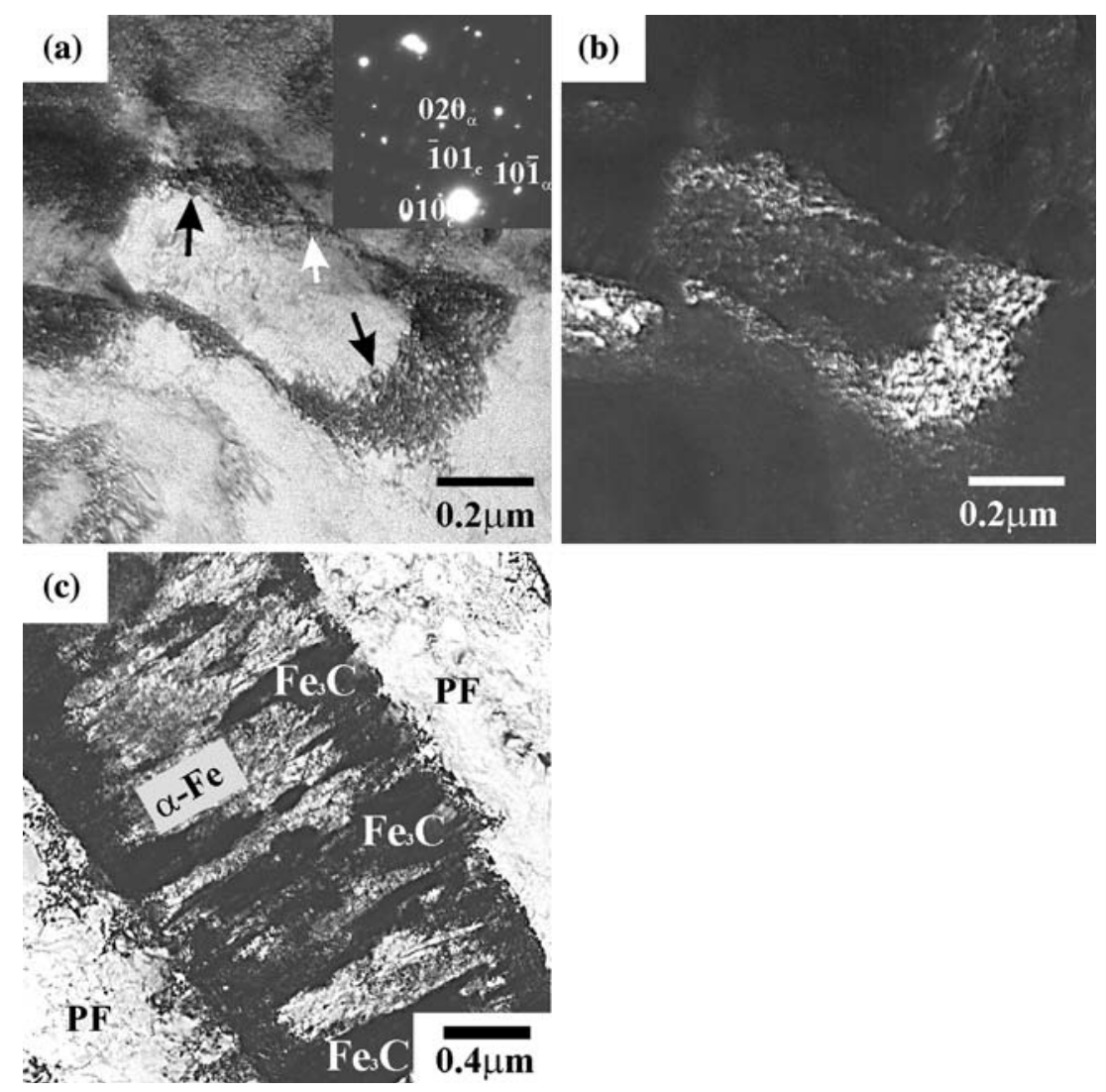

Fig. 10 - (a) and (c) Bright and (b) dark TEM images of DP steel after 10 pct of PS: (a) and (b) formation of cells and formation of carbides on dislocation walls (zone axis is $[101]_{\alpha} / /[101]_{c}$, dark image from $(020)_{(\alpha}$, arrows indicate carbides), and (c) decomposition of retained austenite (arrows indicate ferrite $(\alpha-\mathrm{Fe})$ and carbides).

density in the matrix surrounding the martensite than in the rest of the ferrite matrix. In this case, it is possible for solute carbon to lock dislocations in these local regions.

Another aspect (which affects the BH behavior of DP steel) to note is the larger ferrite grain size in the DP steel than in the TRIP steel. The role of grain boundaries in BH is not completely clear. Grain boundaries could act as low energy sites for carbon, ${ }^{[11]}$ and in this case, the carbon could remain there, which would decrease the $\mathrm{BH}$ response. Alternatively, it was shown that at the temperature of paint coating, it would be possible for carbon to diffuse from the grain boundaries to the grain interiors during treatment, which would increase the $\mathrm{BH}$ response. ${ }^{[25]}$

For the DP steel, there was a permanent increase in strength (Figure 3(b)). This suggests the possible formation of fine particles in the ferrite after $\mathrm{BH}$, which is not expected. Alternatively, the martensite may also form the low-temperature transition carbides and become harder, rather than forming tempering of the martensite, as may be expected.

\section{B. Effect of 5 Pct PS on the BH Behavior of TRIP and DP Steels}

The TRIP and DP steels demonstrated several microstructural features after 5 pct PS and 5 pct PS/BH, such as (1) a decrease in the volume fraction of retained austenite in the TRIP steel after 5 pct PS; (2) the formation of dislocations cells in polygonal ferrite of the TRIP steel as a result not only the deformation, but also of strain-induced transformation of retained austenite to martensite, which leads to the local volume change; (3) formation of fine $\mathrm{Fe}_{3} \mathrm{C}$ carbides in polygonal ferrite and bainite of the TRIP steel; (4) an increase in the average dislocation density of polygonal ferrite but without formation of cell structure in the DP steel; and (5) a higher volume fraction of $\mathrm{Fe}_{3} \mathrm{C}$ carbides that would form in the ferrite of the DP steel, more likely caused by the lower content of $\mathrm{Si}$ in the DP steel.

These microstructural features would control the stress-strain , strain-hardening rate, and strain-hardening exponent behaviors in both steels. First, the TRIP steel showed an upper yield point (Figure 3(a)). In general, the yield point occurs as a result of unlocking the dislocations in ferrite by a high stress or, for case of strong pinning, by creating new dislocations. Moreover, in the case of complex microstructure, such as in the TRIP and DP steels, the additional effect of residual stress and increased dislocation density near the ferritemartensite and ferrite-retained austenite interfaces should be considered. Because the strain-hardening rate curve reflects the microstructural changes during testing, the presence of dislocation pinning after $5 \mathrm{pct} / \mathrm{BH}$ should lead to the transition from continuous to discontinuous strain-hardening behavior. However, the 

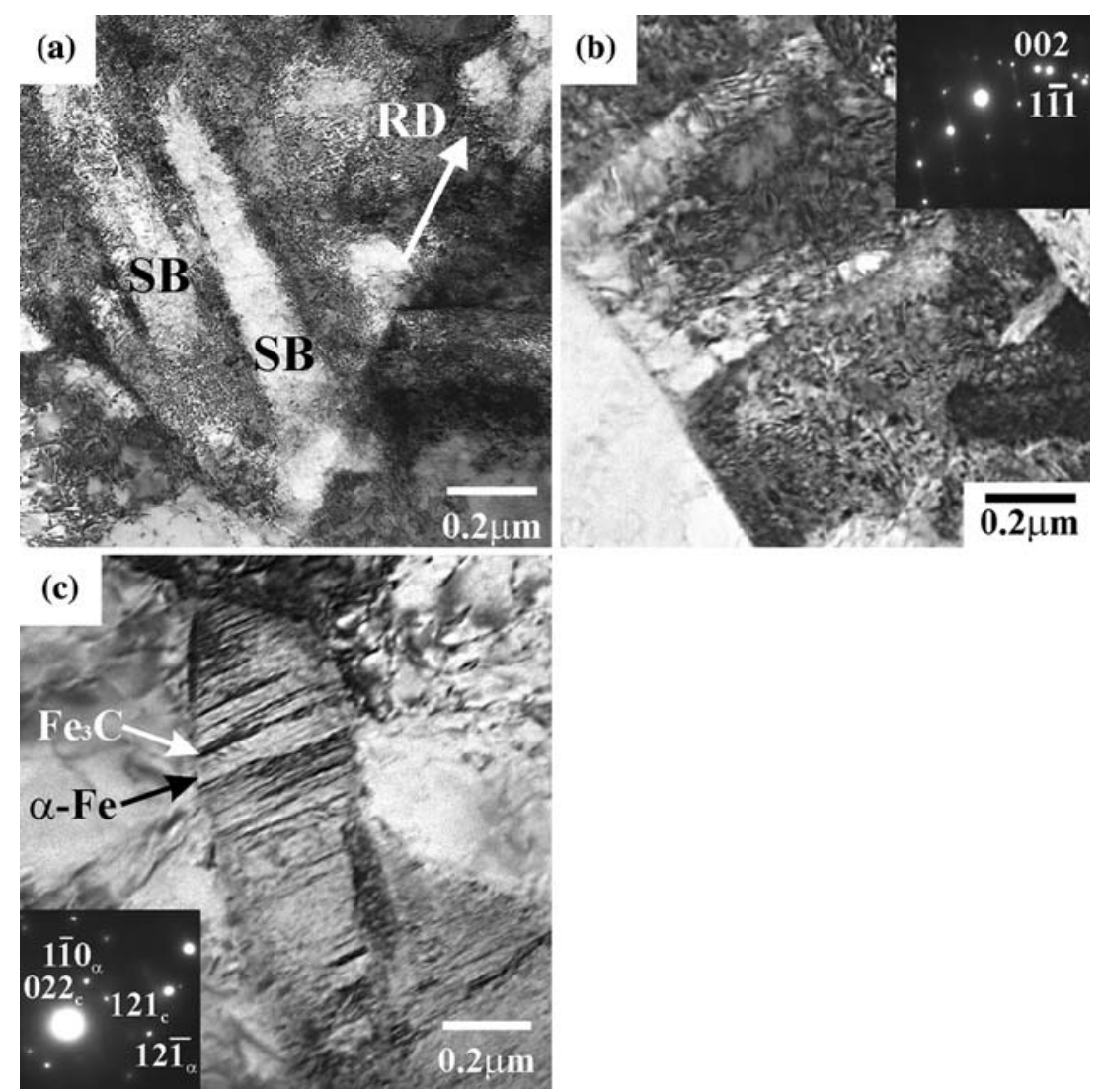

Fig. 11-TEM micrographs of TRIP steel after $(a)$ and (b) 20 pct PS and (c) 20 pct PS/BH: (a) formation of shear bands (SB, shear bands; RD, rolling direction), (b) retained austenite twining (zone axis is $[\overline{1} 10]_{\gamma}$, twin plane is $(\overline{1} 11)_{\gamma}$ ), and (c) decomposition of retained austenite $\left([113]_{\alpha} / /\right.$ $\left.[111]_{c}\right)$.

strain-hardening curve of the TRIP steel after this treatment displayed continuous behavior similar to the as-received or BH conditions (Figure 4(c)). The absence of local minima in the strain-hardening rate curve of the TRIP steel could be a result of the formation of the cell structure in the ferrite after 5 pct PS, which was not observed in the DP steel. The formation of cell structure increased the number of stress fields that can be easily saturated by solute carbon atoms during further $\mathrm{BH}$ treatment in the TRIP steel. On the other hand, with increasing dislocation density, the amount of carbon required to pin these dislocations should increase. It appears that the $\mathrm{BH}$ aging was more rapid in ferrite of the TRIP steel than in the DP steel. Hence, the presence of an upper yield point in the stress-strain curve could be associated with the gradual generation of new dislocations in ferrite during testing to allow the flow stress to drop in the regions of stress concentration.

A further point to consider is that the DP steel demonstrated a steady flow stress behavior after the lower yield point (Figure 3(b)), whereas TRIP steel showed a continuous increase (Figure 3(a)). This difference is most likely related to the strain-induced transformation of retained austenite to martensite during straining and the formation of new dislocations in the TRIP steel.

Both steels after 5 pct PS/BH displayed an increase in the ultimate tensile strength and a decrease in the elongation (Table III). This result could not only be the effect of strain aging in ferrite but also the effect of martensite and bainite strengthening after this treatment. At the $\mathrm{BH}$ temperature, the recovery of dislocations in these phases would be relatively lower than in ferrite, and supersaturation of carbon would lead to much faster BH kinetics. ${ }^{[9,26]}$ This situation would lead to the strengthening effect of martensite and bainite and a general increase in the strength of steels.

\section{Study of Microstructure-Property Relationship after 10 and 20 Pct of PS Followed by BH}

If the microstructure of the TRIP steel after 10 pct $\mathrm{PS} / \mathrm{BH}$ did not display any new microscopic changes as compared with 5 pct PS/BH treatment, the DP showed the essential changes. A microscopic feature observed in the microstructure of the DP steel after 10 pct PS/BH was the formation of a dislocation cell structure with a high number of carbides in the walls (Figures 10(a) and (b)). This, on the one hand, could lead to the work hardening of the ferrite matrix, and this matrix could reach the strain-hardening limit (Figure 3(b)). On the other hand, the formation of cell structure and carbides reduced the amount of carbon available for pinning and would decrease the BH effect (Table III).

Further increase in the PS to $20 \mathrm{pct}$ led to the formation of microbands and shear bands in polygonal ferrite of the TRIP steel because of the total effect of PS 

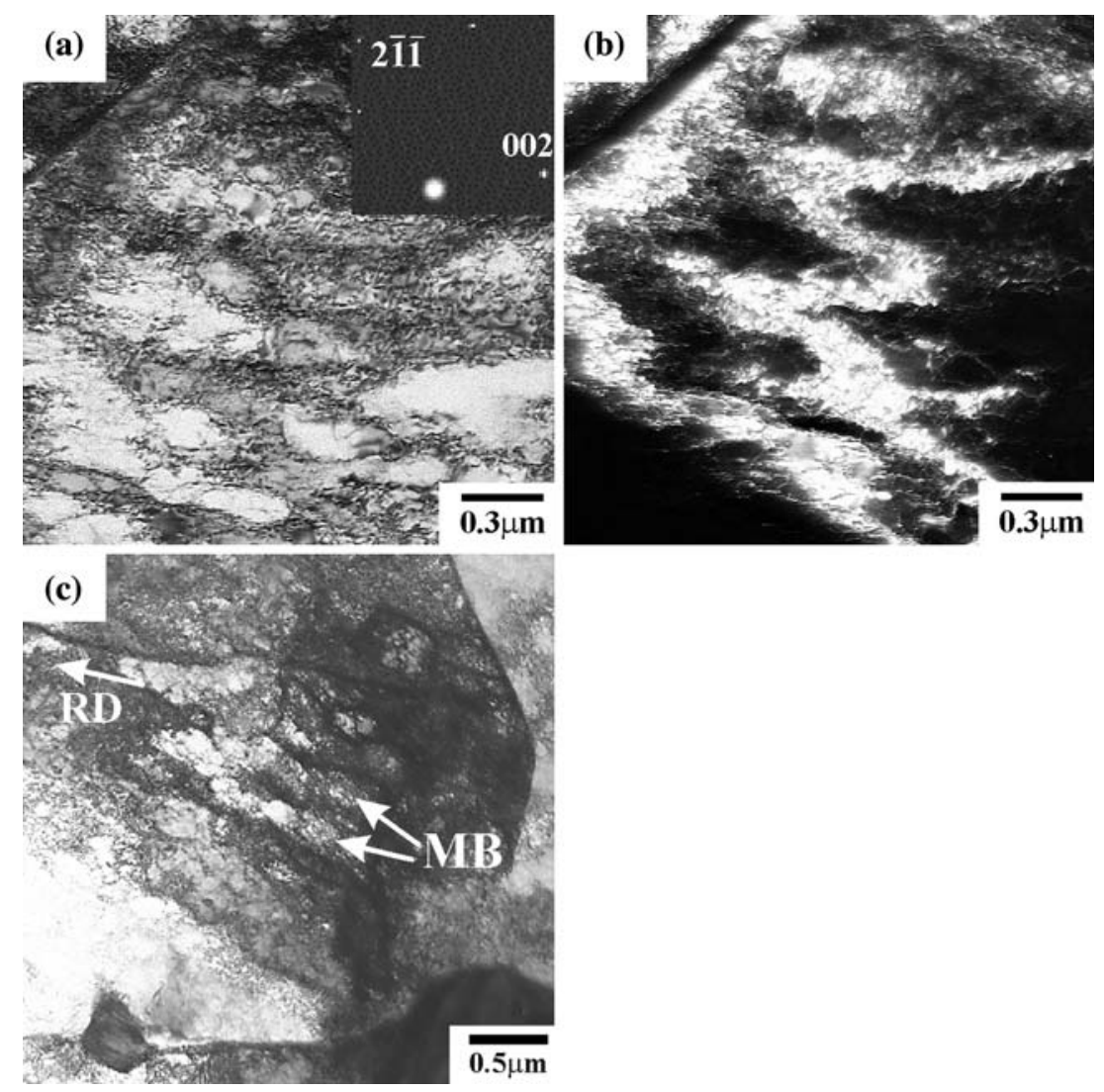

Fig. 12-(a) and (c) Bright and (b) dark TEM micrographs of 20 pct /BH DP steel: $(a)$ and $(b)$ cell formation (dark image from (002) $)_{\alpha}$, and $(c)$ formation of microbands ( $\mathrm{RD}$, rolling direction; $\mathrm{MB}$, microbands).

and strain-induced transformation. As a result, the ferrite matrix showed its strain limit and was not able to produce new mobile dislocations during further testing. The evidence of this effect was the constant flow stress with straining (Figure 3(a)). This contradicts results ${ }^{[27]}$ showing the independence of $\mathrm{BH}$ behavior to the degree of PS and dislocation rearrangement in ferrite. The combined effect of this dislocation structure and formation of lowtemperature $\mathrm{Fe}_{3} \mathrm{C}$ carbides led to the disappearance of the upper yield point and a decrease in the elongation in the TRIP steel (Figure 3(a) and Table III). Moreover, some of the retained austenite crystals that remained in the microstructure after 20 pct PS decomposed during $\mathrm{BH}$ with the formation of ferrite and carbides and did not provide a TRIP effect during testing, which would also affect the mechanical properties.

The $20 \mathrm{pct} / \mathrm{PS}$ of DP steel also led to the formation of a complex dislocation structure in the ferrite with the formation of cells and microbands and to a further increase in the number of carbides after BH. This, as in the case of TRIP steel, led to the work hardening and precipitation hardening of the ferrite matrix. The total effect of these microstructural changes would deteriorate the yield strength and slightly increase the ultimate tensile strength of the DP steel. On the other hand, the upper yield point was still present in the stress-strain curve of the DP steel. This presence could be because of the larger ferrite grain size than in the TRIP steel, which allowed new dislocations to be formed during testing.

\section{CONCLUSIONS}

The microstructure-property relationship in the TRIP and DP steels after intercritical annealing and prestrain/ $\mathrm{BH}$ treatment was analyzed. The most important findings from this research are as follows.

1. The formation of cell, microband, and shear band dislocation structures in polygonal ferrite affected the BH behavior for both the TRIP and DP steels.

2. The strain-induced transformation of retained austenite to martensite in the TRIP steel contributed to the formation of a more complex dislocation structure in the ferrite after PS/BH treatment.

3 . The presence of a high volume fraction of martensite in the DP steel led to the formation of local plastic deformation zones with a high dislocation density, which increased the BH response after PS/ $\mathrm{BH}$ treatment.

4. The formation of carbides in the DP steel in both ferrite and martensite affected the $\mathrm{BH}$ behavior of the DP steel.

\section{ACKNOWLEDGMENTS}

The authors acknowledge the support of the Ford Motor Company and the Australia Research Council (ARC) Linkage Scheme. One of the authors (PDH) also acknowledges the support of an ARC Federation 
fellowship. In addition, the authors acknowledge the assistance of Mr. B. Clarke with tensile testing.

\section{REFERENCES}

1. Y. Sakuma, O. Matsumura, and H. Takechi: Metall. Trans. A, 1991, vol. 22A, pp. 489-98.

2. R.G. Davies: Metall. Trans. A, 1978, vol. 9A, pp. 41-52.

3. A.H. Nakagawa and G. Thomas: Metall. Trans. A, 1985, vol. 16A, pp. $831-40$

4. O. Matsumura, Y. Sakuma, and H. Takechi: Trans. ISIJ, 1987, vol. 27 , pp. $570-79$.

5. M.S. Rashid: Proc. AIME Symp., TMS-AIME, Warrendale, PA, 1994, vol. 244, pp. 1-24.

6. O. Matsumura, Y. Sakuma, and H. Takechi: Scripta Metall., 1987, vol. 21, pp. 1301-06.

7. G.R. Speich and V.A. Demarest: Metall. Trans. A, 1981, vol. 12A, pp. 1419-28.

8. V.F. Zackay, E.R. Parker, D. Fahr, and R. Bush: Trans. ASM, 1967, vol. 60, pp. 252-59.

9. L.J. Baker, S.R. Daniel, and J.D. Parker: Mater. Sci. Technol., 2002, vol. 18, pp. 355-68.

10. A.H. Cottrell and B.A. Bilby: Proc. Phys. Soc., 1949, vol. A62, pp. 49-62.

11. T. Senuma: ISIJ Int., 2001, vol. 41, pp. 520-32.

12. O.M. Faral and T. Hourman: Proc. 41st MWSP Conf., ISS, Baltimore, MD, 1999, vol. XXXVII, pp. 253-64.

13. B.C. De Cooman: Curr. Opin. Solid State Mater. Sci., 2004, vol. 8 , pp. 285-303.
14. M. Kinoshita and A. Nishimoto: CAMP-ISIJ, 1990, vol. 3, pp. $1780-85$.

15. T. Furukawa, H. Mrikawa, M. Endo, H. Takechi, K. Koyama, O. Akisue, and T. Yamada: Trans. ISIJ, 1981, vol. 21, pp. 812-18.

16. T. Waterschoot, A.K. De, S. Vandeputte, and B.C. De Cooman: Metall. Mater. Trans. A, 2003, vol. 34A, pp. 781-91.

17. T. Huper, S. Endo, N. Ishikawa, and K. Osawa: ISIJ Int., 1999, vol. 39, pp. 288-94.

18. A.K. De, S. Vandeputte, and B.C. De Cooman: Scripta Mater., 2001, vol. 44, pp. 695-700.

19. D. Kalish and M. Cohen: Mater. Sci. Eng., 1970, vol. 6, pp. 15666.

20. A.K. De, K. De Blauwe, S. Vandeputte, and B.C. De Cooman: J. Alloys Compd., 2000, vol. 310, pp. 405-10.

21. G.E. Dieter: Mechanical Metallurgy, 2nd ed., McGraw-Hill, New York, NY, 2001, p. 287.

22. B.D. Cullity: Elements of X-Ray Diffraction, Addison-Wesley, London, 1978, pp. 411-15.

23. M. Onink, C.M. Brakman, F.D. Tichelaar, E.J. Mittemeijer, S. van der Zwaag, J.H. Root, and N.B. Konyer: Scripta Metall. Mater., 1993, vol. 29, pp. 1011-16.

24. P.B. Hirsch, R.B. Nicholson, A. Howie, D.W. Pashley, and M.J. Whelan: Electron Microscopy of Thin Crystals, Butterworth and Co, London, 1965, pp. 51-54.

25. K. Sakata, S. Satoh, T. Kato, and O. Hashimoto: ISIJ Int., 1994, pp. 279-88.

26. A.K. De, S. Vandeputte, and B.C. De Cooman: Scripta Mater., 1999, vol. 41, pp. 831-37.

27. A.K. De, K. De Blauwe, S. Vandeputte, and B.C. De Cooman: J. Alloys Compd., 2000, vol. 310, pp. 405-10. 